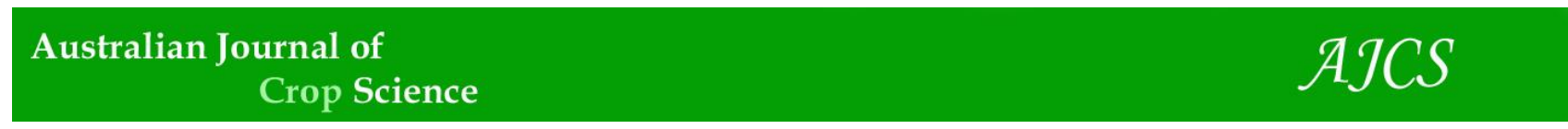

AJCS 13(12):1943-1949 (2019)

ISSN:1835-2707

doi: 10.21475/ajcs.19.13.12.p1494

\title{
Dung decomposition of cattle grazing from mixed pastures of Signalgrass (Brachiaria decumbens Stapf.) and tree legumes
}

\author{
Carolina C. Lira ${ }^{1}$, Jose C. B. Dubeux ${ }^{2}$, Jr., Erick R. S. Santos ${ }^{2 *}$, Mércia V.F. dos Santos ${ }^{3}$, Erinaldo V. de \\ Freitas $^{4}$
}

${ }^{1}$ Instituto Federal de Educação, Ciência e Tecnologia do Ceará, Campus Crateús, Avenue Geraldo Marques Barbosa, 567, Venâncios, Crateús-CE 63700-000, Brazil

${ }^{2}$ North Florida Research and Education Center, 3925 Highway 71, Marianna-FL 32446, The USA

${ }^{3}$ Universidade Federal Rural de Pernambuco, Rua Dom Manoel de Medeiros, S/N/, Dois Irmãos, Recife, PE, Brazil, 52171-900

${ }^{4}$ Instituto Agronômico de Pernambuco - IPA, Av. Gal. San Martin, 1371, Bongi, Recife, PE, Brazil, 50761-000

*Corresponding author: ericksantos13@ufl.edu

\section{Abstract}

The mineralization rate of ruminant manure may influence the fertilization management of pastures. This study aimed to evaluate feces decomposition of heifers grazing signalgrass (Brachiaria decumbens Stapf.) fertilized or not with $\mathrm{N}$, or intercropped with legumes in the dry forest region. Two experiments were conducted; the first one was a CRD that evaluated the evolution of $\mathrm{CO}_{2}$ from a mixture of soil and feces (10:1) during 22 days of incubation in a hermetically sealed bucket with a solution of $\mathrm{NaOH} 0.5 \mathrm{~mol}$ $\mathrm{L}^{-1}$. The second one was a RCBD that evaluated the in situ decomposition of feces in nylon bags in time periods $4,8,16,32,64,128$ and 256 days after incubation above ground. The single negative exponential mathematical model was adequate $(P \leq 0.0001)$ to quantify the $\mathrm{CO}_{2}$ evolution of the mixture of soil and feces, indicating that $78 \%$ of $\mathrm{CO}_{2}$ was released at the beginning of the incubation, especially for the feces collected in the signalgrass pastures intercropped with Gliricidia sepium (Jacq.) Kunth ex Walp. (gliricídia). After the first 5 days, $\mathrm{CO}_{2}$ evolution was more stable. Remaining biomass in the litterbag along decomposition fitted the single negative exponential model $(P<0.001)$. Greater relative decomposition rate $(\mathrm{k})$ of bovine fecal biomass occurred for the $\mathrm{N}$ fertilized signalgrass treatment $\left(\mathrm{k}=0.0031 \mathrm{~g} \mathrm{~g}^{-1} \mathrm{day}^{-1}\right)$ and a lesser rate for the treatment intercropped with Mimosa caesalpiniifolia Benth. (sabiá) $\left(k=0.0018 \mathrm{~g} \mathrm{~g}^{-1} \mathrm{day}^{-1}\right)$. Nitrogen fertilization in signalgrass pasture favored the decomposition of bovine feces at the end of 256 days of incubation.

Keywords: Mimosa caesalpiniifolia, Gliricidia sepium, basal respiration, nutrient cycling, disappearance. Abbreviations: Lignin (LIG), Basal Respiration of Soil and Feces Mixtures (BRSF).

\section{Introduction}

Cattle dung and plant litter deposition are considered the most important factors on pasture nutrient cycling, either by the available quantity or by distribution in the pasture (Braz et al., 2003). Nonetheless, quantity and distribution of these sources of nutrients may vary according to pasture management and utilization. In hay fields, for example, most of the nutrients are exported via forage biomass (Mathews et al., 1994), and the roots are the main pool of nutrients that can cycle back into the system. However, in grazing systems, these nutrients will be recycled (Dubeux et al., 2009), with partial loss via animal product exportation. The nutrient availability from these residues is driven by the decomposition process, which can be affected by the quality of these components (Silva et al., 2012).

Animal excreta mineralization is a process that occurs rapidly and is affected by microbial diversity and decomposition turnover, increasing nutrient availability (Archer and Smeins, 1991). Nutrients are returned to pastures via animal excreta, however, they can be lost to the environment by leaching, volatilization, erosion, denitrification, and runoff (Dubeux et al., 2014). Alternatively, these nutrients can also be immobilized by soil microorganisms and become unavailable to plants (Johnson et al., 2000).

Decomposing organisms, like earthworms and dung beetles, affect the decomposition rate of feces and plant litter (Follett and Wilkinson, 1995). In addition, the physical degradation of the feces is also affected by the weather, with rainfall and temperature being considered the most important weather factors (Souto et al., 2005).

Grazing animals remove plant fractions, which are reduced to smaller particles through chewing and rumination (Dubeux et al., 2009; Carvalho et al., 2010). Thus, among other factors, fecal composition varies with animal nutrient requirement, water ingestion, feeding parameters, and feed efficiency (Azeez et al., 2009). The amount of nutrient returned to the soil via feces and urine can be estimated by 
knowing the forage type that the animal has consumed and its nutritional requirement (Haynes and Williams, 1993). Introduction of legumes into warm-season grass pastures improves animal diet and biological $\mathrm{N}_{2}$ fixation (Russelle, 2008), as well as enhances plant litter quality (Silva et al., 2012). Legume crude protein and in vitro dry matter digestibility are usually greater than the ones observed in warm-season grasses, yet legumes present lower C:N and lignin: $\mathrm{N}$ ratios (Bacellos et al., 2008; Aroeira et al., 2005), which favors micro-organism activity in the mineralization of plant residues and animal feces.

From the importance of nutrient cycling in pasture ecosystems via ruminant excreta, as well as the decomposition rate of these residues, this study aimed to evaluate the decomposition of feces from heifers grazing mixed grass-tree legume pastures and grass-only pastures in the Pernambuco's rainforest region.

\section{Results and Discussions}

\section{Chemical composition of feces prior the incubation}

There was a significant difference in the feces chemical composition before the incubation for $\mathrm{P}$ and $\mathrm{K}$ concentrations (Table 1). The feces of the animals that were grazing the mixed pasture of leucaena or sabia combined with signalgrass had lower $P$ concentration $\left(4.8\right.$ and $3.4 \mathrm{~g} \mathrm{~kg}^{-}$ 1 , respectively) when compared with the animals that were grazing $\mathrm{N}$-fertilized signalgrass or signalgrass-mororó $(6.8$ and $6.4 \mathrm{~g} \mathrm{~kg}^{-1}$, respectively). The $\mathrm{N}$-fertilized signalgrass $\mathrm{K}$ concentration $\left(20.3 \mathrm{~g} \mathrm{~kg}^{-1}\right)$ was not statistically different from the mixture signalgrass-leucaena $\left(15.0 \mathrm{~g} \mathrm{~kg}^{-1}\right)$, however, it was greater than all the other treatments (13.5 g $\mathrm{kg}^{-1}$, average). There was no difference among treatments before the incubation time for $\mathrm{N}, \mathrm{Ca}, \mathrm{Mg}$ concentrations, $\mathrm{C}: \mathrm{N}$, and lignin: $\mathrm{N}$ ratio. The fibrous portion of the feces may comprise 47 to $68 \%$ of the total biomass (Haynes \& Williams, 1993), and it can vary in composition according to the animal diet.

It was estimated, in a separated behavioral study, the preference for each component of the pasture (legume or grass) by recording the time cattle spent browsing on each species. The percent of the time that animals spent browsing legumes ranged from $9.1-7.6 \%, 14.0-3.6 \%, 3.8-0.8 \%$, and $1.8-1.3 \%$, for the mixtures with sabia, leucaena, gliricídia, and mororo, respectively (Santos et al., 2011).

Cattle are grazers and that might explain the reduced time spent browsing the tree legumes. Celaya et al. (2007) observed $75-99 \%$ of herbaceous components (mostly grasses) in bovine diet, while its participation on small ruminants ranged from 15 to $64 \%$. Benefits of adding legumes to grass pastures in the animal diet do not only occur via ingestion of legumes; there is also an increase of crude protein in the associated grass due to greater availability of soil N (Suter et al., 2015).

\section{Parameters observed in the basal respiration of soil and feces}

The basal respiration is defined as the sum of all metabolic functions where $\mathrm{CO}_{2}$ is produced, representing the total decomposition rate, once $\mathrm{CO}_{2}$ is released during aerobic biodegradation of most organic compounds (Silva et al.,
2007). The microbial respiration evaluation estimates soil microorganism activity, which mimics the soil OM decomposition rate (Figueiredo et al., 2012). The single negative exponential mathematical model was fitted to the basal respiration of soil and feces (BRSF) curve for the different incubation times.

The $\mathrm{CO}_{2}$ evolution is an indicator of the microbial activity in the decomposition of the native OM or the OM added to the soil (Heal et al., 1997, Wagner and Wolf, 1999). All treatments presented an elevated $\mathrm{CO}_{2}$ production at the beginning of the incubation (Fig. 1), however, after the $5^{\text {th }}$ incubation day, there was a reduction on $\mathrm{CO}_{2}$ emission. Greater $\mathrm{CO}_{2}$ emission at the beginning of the incubation time occurred because of faster decomposition of the labile material by the microorganisms. After 5 days, $78.6 \%$ of the material of the signalgrass-leucaena mixture was decomposed, with a posterior reduction in the decomposition rate. During the same time, $\mathrm{CO}_{2}$ emission from unfertilized signalgrass was $54.3 \%$ and it was significantly different from signalgrass-leucaena, however, no difference among treatments was found after the initial phase (Fig. 1). Among the factors that may have contributed to faster decomposition rate at the beginning (first $24 \mathrm{~h}$ ), the $\mathrm{C}: \mathrm{N}$ and lignin: $\mathrm{N}$ ratios before the incubation time may have the greatest effect, once these parameters dictate decomposition rates. At the beginning of the incubation, there was a greater amount of $\mathrm{N}$, which results in faster decomposition. After some of this $\mathrm{N}$ is decomposed, the more recalcitrant material is left, resulting in reduced decomposition.

The chemical composition of the residue may alter the biomass microbial community structure and affect its soil $\mathrm{C}$ use efficiency, resulting in different $\mathrm{C}$ mineralization from varied organic sources (Silva et al., 2010). Commonly, residues with C:N ratio lower than 20:1 present a faster decomposition rate than materials with values above this ratio. According to Nicolardot et al. (2001), the C:N ratio is the most used feature to predict $\mathrm{N}$ soil availability during the decomposition of organic materials.

\section{Biomass disappearance and nutrient release of cattle dung during decomposition}

There was a treatment $x$ decomposition time interaction $(P<$ 0.001) for the fecal $O M$ disappearance of the samples incubated on the soil surface. The single negative exponential mathematical model was fitted to explain the curve of the remaining biomass according to the incubation times (Fig. 2).

Besides the biomass values at beginning of the incubation time being close ( $8 \%$ of disappearance in the first 32 days), the $\mathrm{N}$-fertilized signalgrass presented greater biomass relative decomposition rate $\left(k=0.0031 \mathrm{~g} \mathrm{~g}^{-1} \mathrm{dia}^{-1}\right)$, with $55 \%$ of OM decomposition in 256 incubation days, where the average for all treatments was $48 \pm 7 \%$. Brady and Weill (2002) suggested that disappearance and degradation may vary according to environmental conditions, ranging from 30 d to 17 mo (Weeda, 1967), and it can possibly take 2.5 y until complete decomposition (Hoffmann et al., 2001).

The lowest relative decomposition rate was observed for the signalgrass-sabiá mixture $\left(\mathrm{k}=0.0018 \mathrm{~g} \mathrm{~g}^{-1} \mathrm{~d}^{-1}\right)$, with $37 \%$ of the material decomposed during the same time. 
Table 1. Element composition ( $\mathrm{N}, \mathrm{P}, \mathrm{K}, \mathrm{Ca}, \mathrm{Mg}$ ), C:N ratio, and LIG:N ratio of feces from heifers grazing signalgrass monocultures or mixed with legumes before the incubation time

\begin{tabular}{llllllll}
\hline Treatment & \multicolumn{1}{c}{$\mathrm{N}$} & \multicolumn{1}{c}{$\mathrm{P}$} & $\mathrm{K}$ & $\mathrm{Ca}$ & $\mathrm{Mg}$ & $\mathrm{C}: \mathrm{N}$ & $\mathrm{LIG}: \mathrm{N}$ \\
\hline Signalgrass & $\mathrm{g} \mathrm{kg}^{-1}$ & & & & & & \\
N-Fertilized & $16.7 \mathrm{a}$ & $5.2 \mathrm{ab}$ & $14.0 \mathrm{~b}$ & $6.4 \mathrm{a}$ & $3.9 \mathrm{a}$ & $22.5 \mathrm{a}$ & $3.6 \mathrm{a}$ \\
Gliricídia & $16.9 \mathrm{a}$ & $6.8 \mathrm{a}$ & $20.3 \mathrm{a}$ & $8.5 \mathrm{a}$ & $4.5 \mathrm{a}$ & $23.4 \mathrm{a}$ & $4.3 \mathrm{a}$ \\
Leucaena & $18.5 \mathrm{a}$ & $5.6 \mathrm{ab}$ & $14.9 \mathrm{~b}$ & $7.1 \mathrm{a}$ & $4.0 \mathrm{a}$ & $19.3 \mathrm{a}$ & $4.1 \mathrm{a}$ \\
Mororó & $17.9 \mathrm{a}$ & $4.8 \mathrm{~b}$ & $15.0 \mathrm{ab}$ & $6.3 \mathrm{a}$ & $5.1 \mathrm{a}$ & $19.8 \mathrm{a}$ & $2.8 \mathrm{a}$ \\
Sabiá & $16.3 \mathrm{a}$ & $6.4 \mathrm{a}$ & $14.6 \mathrm{~b}$ & $7.9 \mathrm{a}$ & $5.0 \mathrm{a}$ & $22.3 \mathrm{a}$ & $3.1 \mathrm{a}$ \\
\hline SE & $17.8 \mathrm{a}$ & $3.4 \mathrm{~b}$ & $10.5 \mathrm{~b}$ & $8.4 \mathrm{a}$ & $4.6 \mathrm{a}$ & $20.4 \mathrm{a}$ & $5.9 \mathrm{a}$ \\
\hline
\end{tabular}

Different letters in the same column indicate significant difference according to Tukey's test $(P \leq 0.05)$. LIG = lignin; N-Fertilized $=\mathrm{N}$-Ferilized signalgrass; gliricídia $=$ signalgrass-gliricídia; leucaena $=$ signalgrass-leucaena; mororó $=$ signalgrass-mororó; sabiá = signalgrass- sabiá.

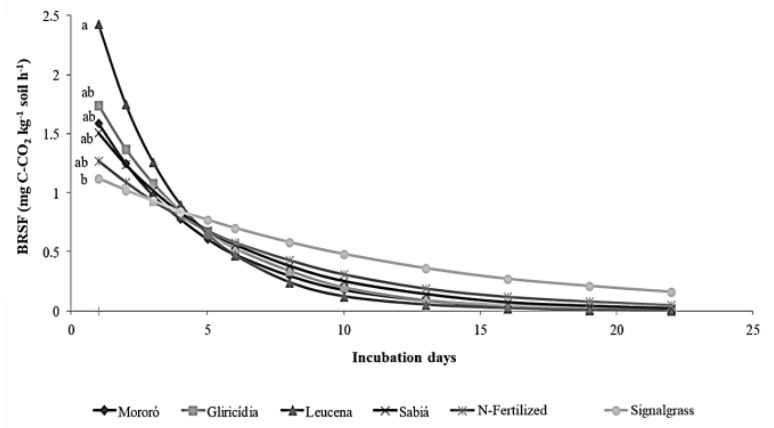

Fig 1. Basal Respiration of Soil and Feces Mixtures (BRSF) from heifers grazing signalgrass monocultures or signalgrass-legume mixed pastures. Y Signalgrass $=1.23^{-0.0936 t}(P<0.0001)$, Y N-Fertilized signalgrass $=1.49^{-0.1563}(P<0.0001)$, Y Gliricídia $=2.211^{-0.2325 t}$ $(P<0.0001)$, Y Leucaena $=3.39^{-0.3307 t}(P<0.0001)$, Y Mororó $=2.02^{-2.2391 \mathrm{t}}(P<0.0001)$, Y Sabiá $=1.89^{-0.1984 t}(P<0.0001) . \mathrm{N}-$ Fertilized = N-Ferilized signalgrass; gliricídia = signalgrass-gliricídia; leucaena = signalgrass-leucaena; mororó = signalgrass-mororó; sabiá = signalgrass- sabiá.

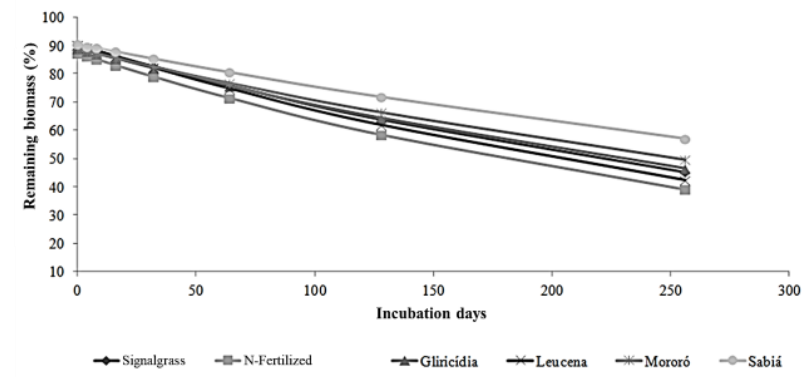

Fig 2. Remaining biomass (\%) from feces of heifers grazing signalgrass monocultures or signalgrass-legume mixed pastures during 264 incubation days. N-Fertilized = N-Ferilized signalgrass; gliricídia = signalgrass-gliricídia; leucaena = signalgrass-leucaena; mororó = signalgrass-mororó; sabiá = signalgrass- sabiá.

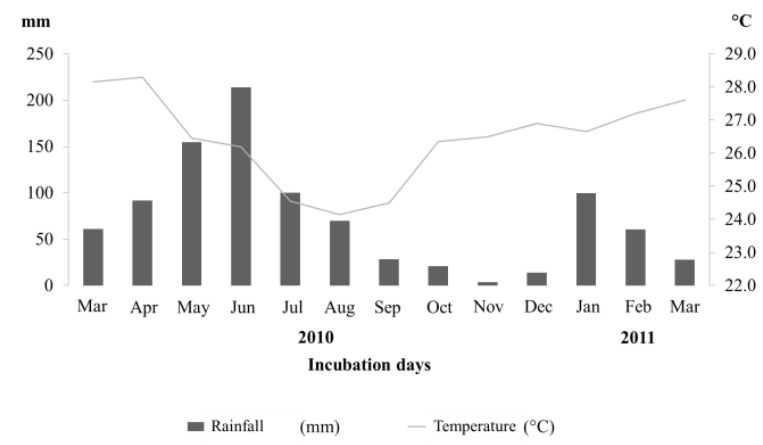

Fig 3. Rainfall and average monthly temperature during the experimental time, Itambe-PE, Brazil. 


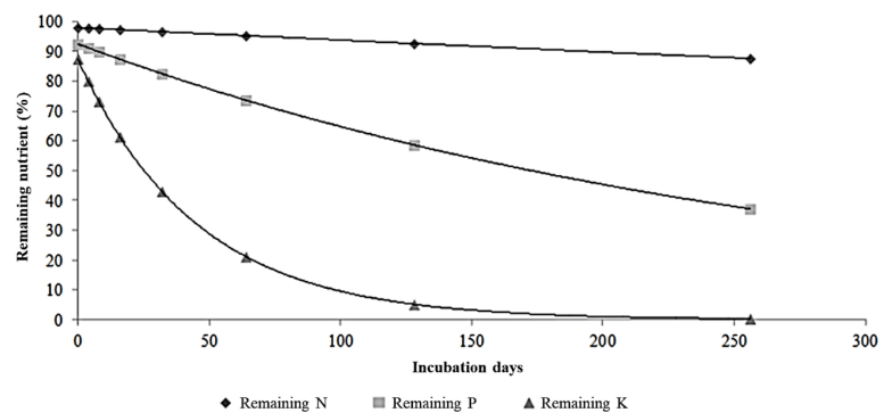

Fig 4. Remaining $N, P$, and $K$ in feces of heifers grazing signalgrass monocultures or signalgrass-legume mixed pastures during 264 incubation days. $Y($ remaining $N)=97.94^{-0.000439 t}(P<0.0001) ; Y($ remaining $P)=92.429^{-0.004 t}(P<0.0001) ; Y($ remaining K $)=87.357$ ${ }_{0.022 t}(P<0.0001)$.

The biomass relative decomposition rate $(k)$ is affected by factors as residue quality, temperature, soil humidity, and existing microbiota (Heal et al., 1997; Wagner and Wolf, 1999). Thus, rainfall distribution (Fig. 3) during the incubation time may have affected the feces decomposition, mainly for the 64 and 128 incubation days, when the average rainfall was $16.67 \mathrm{~mm}$ and the accumulated was $66.17 \mathrm{~mm}$. According to Silva et al. (2010), the dung $\mathrm{CO}_{2}$ emission, when submitted to the decomposition process, is significantly reduced when exposed to hydric stress, because of the reduction in microbial activity.

Souto et al. (2005) evaluating dung decomposition of four species (asinine, bovine, caprine, and ovine) at the soil surface or at $10-\mathrm{cm}$ depth in the Paraiba's (a state located in the Brazilian northeast) semi-arid region, reported $5 \%$ of decomposition after $30-\mathrm{d}$ incubation, and posterior gradual increase, reaching $28 \%$ at day 90 . These results were affected by the low rainfall at the initial incubation times (January and February 2011), with precipitation of 37.6 and $2.9 \mathrm{~mm}$, respectively. In March (90 d after incubation), the precipitation was $\approx 195 \mathrm{~mm}$, which resulted in greater decomposition rate for the incubated material. In addition, the greater decomposition occurred when the feces were at $10-\mathrm{cm}$ depth; this was related to greater soil moisture variation in the soil surface, which retains less humidity, as a function of evapotranspiration loss, resulting in less microbial activity and $\mathrm{OM}$ decomposition (Freitas et al., 2012).

Lower legume preference by the animals when compared to the grasses, may not have affected the fecal C:N ratio, once no difference among treatments was observed $(P=0.4737)$ before the incubation. Lignin: $\mathrm{N}$ ratio explains better longterm decomposition than other ratios (Dubeux et al., 2006). Thus, lignin: $\mathrm{N}$ ratio can be a determinant factor for the biomass decomposition, especially with longer incubation times. Nonetheless, no difference among treatments before the incubation $(P=0.5857)$ or during the decomposition times $(P=0.6863)$ was observed for lignin: $\mathrm{N}$ ratio.

There was a decomposition time difference $(P<0.001)$ for $N$, $P$, and $K$ concentrations following the single negative exponential model (Fig. 4), however, there was no difference among treatments. The relative decomposition rate ( $k$ ) for the remaining $\mathrm{N}$ was $0.00043 \mathrm{~g} \mathrm{~g}^{-1} \mathrm{~d}^{-1}$, resulting in a net mineralization of $16 \%$ after $256 \mathrm{~d}$ of incubation when compared to the initial value in the samples. Hirata et al. (2009) developed a study in Japan with a $17^{\circ} \mathrm{C}$ average temperature and observed the $\mathrm{N}$ disappearance rate ranging from 0.0005 to $0.0016 \mathrm{~g} \mathrm{~g}^{-1} \mathrm{~d}^{-1}$. Silva et al. (2012) observed a disappearance of $0.00029 \mathrm{~g} \mathrm{~g}^{-1} \mathrm{~d}^{-1}$ for signalgrass plant litter. This value was inferior to the values found for the plant litter of the leguminous forage Calopogonium mucunoides (calopo; $\mathrm{k}=0.0013 \mathrm{~g} \mathrm{~g}^{-1} \mathrm{~d}^{-1}$ ) and the mixture of signalgrass with calopo $\left(k=0.0024 \mathrm{~g} \mathrm{~g}^{-1} \mathrm{~d}^{-1}\right)$. Nitrogen mineralization occurs slower in feces than in plant material; this is caused by greater $\mathrm{C}: \mathrm{N}$ ratio and $\mathrm{C}$ concentration in the feces than in the plant material (Haynes and Williams, 1993). Considering that the decomposition of the residues is affected by the rainfall, the low precipitation may have affected the $\mathrm{N}$ disappearance rate. In addition, this nutrient $(\mathrm{N})$ may have been immobilized during the incubation time.

After $256 \mathrm{~d}$ of incubation, $60 \%$ of the $\mathrm{P}$ was released $(\mathrm{k}=$ $0.004 \mathrm{~g} \mathrm{~g}^{-1} \mathrm{~d}^{-1}$ ). On the other hand, $99.6 \%$ of the $\mathrm{K}$ was released at the end of the incubation time, with a $\mathrm{k}=0.0022$ $\mathrm{g} \mathrm{g}^{-1} \mathrm{~d}^{-1}$. This indicates that this mineral is not related to more complex organic materials and is easily released by leaching, in contrast to $\mathrm{N}$ and $\mathrm{P}$, which are more depended on microbial activity, converting into inorganic forms (Braz et al., 2002).

\section{Materials and Methods}

\section{Experimental site}

The experiment was conducted at the Instituto Agronômico de Pernambuco (IPA), at Itambe's Experimental Station, located at $07^{\circ} 25^{\prime} \mathrm{S}$ and $35^{\circ} 06^{\prime} \mathrm{W}$, physiographic microregion of the dry forest zone, at $190 \mathrm{~m}$ above sea level, with an annual rainfall of $1300 \mathrm{~mm}$ and average annual temperature of $25^{\circ} \mathrm{C}$ (CPRH, 2003; ITEP, 2010). Annual rainfall and average monthly temperature during the experimental time (from March 2010 to March 2011) were $73 \mathrm{~mm}$ and $26.4{ }^{\circ} \mathrm{C}$, respectively (Fig. 3).

\section{Tree legume establishment, treatments, and field experimental design}

The experimental area was allocated in a randomized complete block design with six treatments and four replicates, with each paddock measuring $660 \mathrm{~m}^{2}$ (33 x 20-m). We analyzed feces decomposition from heifers that were grazing signalgrass (Brachiaria decumbens Stapf.) monocultures or mixtures of signalgrass with tree legumes; sabiá (Mimosa caesalpiniifolia Benth.), leucaena (Leucaena leucocephala Lam.), mororó [Bauhinia cheilantha (Bong) Steud] or gliricídia [Gliricidia sepium (Jacq.) Kunthe], hence, feces from heifers grazing each one of the two monocultures 
or one the four grass-legume combinations composed the six treatments. Legume seedlings were transplanted in July 2008 to already established signalgrass pastures. They were planted in 10-m long double strips, with $1 \mathrm{~m}$ between strips and $0.5 \mathrm{~m}$ between plants in the same line; each mixed paddock had three double strips of tree legumes. In addition to the four grass-legume pastures, there were two signalgrass monoculture treatments; one of them did not have $\mathrm{N}$ fertilization (unfertilized signalgrass) and the other one received $60 \mathrm{~kg} \mathrm{~N} \mathrm{ha}^{-1} \mathrm{yr}^{-1}$ ( $\mathrm{N}$-fertilized signalgrass). The fertilization was applied two times $\left(30 \mathrm{~kg} \mathrm{~N} \mathrm{ha}^{-1}\right.$ each application) as urea-N, with the first was application occurring at the beginning of the raining season (March 2010) and the second one 56 days after the first.

Six crossbred heifers (Holstein-Bos indicus); with an average weight of $255 \pm 50.5$ and an average age of $22 \pm 6.4$ months were used. The stocking rate was one animal unit $(450 \mathrm{~kg}$ of body weight) per paddock with a grazing cycle of 28 days (seven grazing days and 21 days of regrowth interval). In all the paddocks, heifers had access to water and mineral salt. Each animal was assigned to the same treatment across blocks, in such a way that after seven grazing days in one block, they would move to the next one, coming back to the first block they grazed 21 days after they left the paddock. Using this approach, cattle had access to similar treatment across paddocks.

\section{Sampling of the fecal patches}

The sampling took place in March 2010, in the morning, during the second grazing day. Three patches were collected per paddock, right after each defecation event. Samples were collected carefully in order to not contaminate them with soil. The feces were placed into aluminum plates, the fresh weight was recorded, and then the samples were dried in a forced air-drying oven at $55{ }^{\circ} \mathrm{C}$ for $72 \mathrm{~h}$. Thereafter, a composite sample of the three patches (for each paddock) was made. A subsample was used for the decomposition trial, which evaluated the organic matter disappearance and nutrient release in different incubation times, and another subsample was ground to pass in a $2-\mathrm{mm}$ screen mill to determine the chemical composition and $\mathrm{CO}_{2}$ evolution, which was determined by the basal respiration of soil and feces mixtures.

\section{Determination of basal respiration of soil and feces mixtures}

Soil at the Experimental station was collected from 0- to 20$\mathrm{cm}$ depth, sieved to pass in a $2-\mathrm{mm}$ screen, in order to remove fragments from animal and plant depositions. Thereafter, a $400-\mathrm{mL}$ beaker was used to mix $300 \mathrm{~g}$ of soil with $30 \mathrm{~g}$ of feces ground to pass into a 2-mm sieve. The mixture humidity was elevated to $80 \%$ of the field capacity, which was kept with water reposition after five days of evaluation. Each beaker containing the mixture was placed inside a 3- $\mathrm{L}$ capacity bucket, together with a $50-\mathrm{mL}$ beaker with $20 \mathrm{~mL}$ with a solution of $\mathrm{NaOH} 0.5 \mathrm{~mol} \mathrm{~L}^{-1}$. The bucket was then hermetically sealed to avoid the entrance of external $\mathrm{CO}_{2}$ or leakage of the produced internal $\mathrm{CO}_{2}$. The $\mathrm{NaOH} 0.5 \mathrm{~mol} \mathrm{~L}^{-1}$ solution was responsible to capture the $\mathrm{CO}_{2}$ that evolved through the respiration process, caused by the micro-organisms decomposition process. At each evaluation time, this solution was replaced for a new incubation. The quantification of the evolved $\mathrm{CO}_{2}$ was made by titration, as described by Silva et al. (2007). The trial was composed of 24 buckets (experimental units) in order to allocate six treatments with four replicates in a complete randomized design. Three additional buckets were used as blanks; they were used to determine the $\mathrm{CO}_{2}$ evolution standard. Treatments were the same described above in the sampling of the fecal patches. The incubation time was $22 \mathrm{~d}$, with a replacement of the solution in the first seven days occurring each $24 \mathrm{~h}$. From $7^{\text {th }}$ to $12^{\text {th }}$ day, from the $12^{\text {th }}$ to $17^{\text {th }}$ day, and from the $17^{\text {th }}$ to the $22^{\text {nd }}$ day, the solution was replaced every 48, 72, and $96 \mathrm{~h}$, respectively (Silva et al., 2007). Data were analyzed using the PROC MIXED from SAS (SAS Inst., 2001), and the days were considered repeated measures. After the ANOVA procedure, the negative simple exponential model was applied for the mineralized carbon in the mixture of soil and feces (Wagner and Wolf, 1999) using proc nlin from SAS.

\section{In situ cattle dung decomposition}

Nylon bags were used for in situ incubation of the cattle dung on the soil surface. The trial was performed from June 23,2010 , to February 26, 2011, in an area located close to the paddocks where the samples were collected. The incubation times corresponded to the number of days the bags were incubated before their removal from the soil surface, and they were $0,4,8,16,32,64,128$, and 256 days, with four replications per incubation time, and were organized in a randomized complete block design with four replicates.

The nylon bags used in the trial measured $15 \times 30 \mathrm{~cm}$, with a porous space of $75 \mu \mathrm{m}$. The bags were placed in a drying oven at $65{ }^{\circ} \mathrm{C}$ for $72 \mathrm{~h}$ and weighted thereafter. The feces were broken into smaller fractions (approximately $5 \mathrm{~cm}$ in diameter), and then $30 \mathrm{~g}$ were placed inside the nylon bags. The feces were not ground in order to maintain its original contact surface for micro-organisms activity (Dubeux et al., 2006).

Nylon bags with the feces were then placed above the soil surface, together with some empty nylon bags that were used as blanks for each incubation time. The blanks were used in order to estimate the time effect on the bag decomposition, and utilize this information as a correction factor for the other incubated materials. At the end of each incubation time, a brush was used to clean the nylon bags after they were removed from the soil, in order to clean the outside material on the bag surface. After that, the bags were dried again at $65^{\circ} \mathrm{C}$ for $72 \mathrm{~h}$, and once again the bags were weighted. The samples were analyzed for dry matter and ash, in order to estimate the liquid mineralization that occurred along the times.

Dry matter, organic matter, and $\mathrm{N}$ concentration were determined according to the methods described by Silva and Queiroz (2002). Carbon concentration was determined by the method described by Bezerra Neto and Barreto (2004), and lignin was analyzed following the method described by Van Soest et al. (1991) in an autoclave, as described by Pell and Schofield (1993). The samples were submitted to nitroperchloric digestion (Bezerra Neto and Barreto, 2004) in order to determine $\mathrm{P}, \mathrm{K}, \mathrm{Ca}$, and $\mathrm{Mg}$. Phosphorous and $\mathrm{K}$ 
Mehlich-1 extractable were quantified by colorimetry and flame photometry, respectively (Embrapa, 1979). Exchangeable $\mathrm{Ca}$ and $\mathrm{Mg}$ were extracted with $\mathrm{KCl} 1 \mathrm{~mol} \mathrm{~L}^{-1}$ and quantified by atomic absorption spectrophotometry (Embrapa, 1979).

The means for the decomposition times were analyzed using the PROC MIXED from SAS (SAS Inst., 2001). After the ANOVA, a single exponential model was used to determine the percentage of biomass disappearance, on OM basis, remaining $N, C: N, C: P$, and lignin: $N$ ration, which was described by the equation:

$$
Y=B 0^{e-k t}
$$

Where: $Y$ in the proportion of remaining biomass (or nutrient) at the days $t, B O$ is the disappearance constant and the $k$ is the relative decomposition rate.

\section{Conclusions}

Decomposition of feces from heifers grazing $\mathrm{N}$-fertilized signalgrass pastures was greater than feces from heifers grazing on signalgrass-tree legume pastures after $256 \mathrm{~d}$ of incubation. In the beginning, the feces decomposition was accelerated by the presence of legumes in the pastures, resulting in a greater $\mathrm{CO}_{2}$ emission. The microbial activity was reduced along the incubation time, resulting in a more stable decomposition.

\section{References}

Archer S and Smeins FE (1991) Ecosystem-level processes. In: Heitschmidt RK, Stuth JW (Ed). Grazing management: an ecological perspective. Portland, Oregon.109-139.

Aroeira LJM, Paciullo DSC, Lopes FCF, Morenz MJF, Saliba ES, Silva JJ, Ducatti C. (2005) Disponibilidade, composição bromatológica e consumo de matéria seca em pastagem consorciada de Brachiaria decumbens com Stylosanthes guianensis. Pesqui Agropecu Bras. 40(4).

Azeez JO and Van Averbeke W (2009) Nitrogen mineralization potential of three animal manures applied on a sandy clay loam soil. Bioresource Technol. 101:56455651.

Barcellos AO, Ramos AKB, Vilela L, Martha Jr GB (2008) Sustentabilidade da produção animal baseada em pastagens consorciadas e no emprego de leguminosas exclusivas, na forma de banco de proteína, nos trópicos brasileiros. Rev Bras Zootecn. 37:51-67.

Bezerra Neto E and Barreto LP (2004) Métodos de análises químicas em plantas. Recife, UFRPE, Imprensa Universitária. 165.

Brady NC and Weil RR (2002) The nature and properties of soils, 13th edn. Prentice-Hall, New Jersey. 960.

Braz SP, Nascimento Jr. D, Cantarutti RB, Regazzi AJ, Martins CE, Fonseca DM (2002) Disponibilização dos nutrientes das fezes de bovinos em pastejo para a forragem. Rev Bras Zootecn. 31:1614-1623.

Braz SP, Nascimento Jr. D, Cantarutti RB, Martins CE, Fonseca DM, Barbosa RA (2003) Caracterização da distribuição espacial das fezes por bovinos em uma pastagem de Brachiaria decumbens. Rev Bras Zootecn. 32(4):787-794.

Carvalho PC, Anghinoni I, Moraes A, Souza ED, Sulc RM, Lang CR, Flores JPC, Lopes MLT, Silva JLS, Conte O, Wesp CL, Levien R, Fontaneli RS, Bayer C (2010) Managing grazing animals to achieve nutrient cycling and soil improvement in no-till integrated systems. Nutr Cycl Agroecosys. 88:259-273.

Celaya R, Oliván M, Ferreira LMN, Martínez A, García U, Osoro K (2007) Comparison of grazing behavior, dietary overlap and performance in non-lactating domestic ruminants grazing on marginal heathland areas. Livest Sci. 106:217-278.

CPRH - Companhia Pernambucana do Meio Ambiente. Diagnóstico sócio ambiental do litoral norte de Pernambuco (2003) Recife. 214.

Dubeux Jr. JCB, Sollenberger LE, Interrante SM, Vendramini JMB, Stewart Jr. RL (2006) Litter decomposition and mineralization in bahiagrass pastures managed at different intensities. Crop Sci. 46:1305-1310.

Dubeux Jr. JCB, Sollenberger LE, Gaston LA, Vendramini JMB, Interrante SM, Stewart Jr RL (2009) Animal behavior and soil nutrient redistribution in continuously stocked pensacola bahiagrass pastures managed at different intensities. Crop Sci. 49:1503-1510.

Dubeux Jr. JCB, Sollenberger LE, Silva HMS, Souza TC, Mozley III EL, Santos ERS (2014) Nutrient cycling in tropical pastures: what do we know? In: VII SIMFOR - 7th Symposium on strategic management of pasture. At: Viçosa, MG, Brazil.

Empresa Brasileira de Pesquisa Agropecuária, EMBRAPA (1979) National Soil Research Center, National service for soil survey and soil conservation. Manual of methods for soil analyses. EMBRAPA Solos, Rio de Janeiro, Brazil.

Figueiredo CC, Ramos MLG, McManus CM, Menezes AM (2012) Mineralização de esterco de ovinos e sua influência na produção de alface. Hortic Bras. 30(1):175-179.

Follet RF and Wilkinson SR (1995) Nutrient management of forages. Follet RF and Wilkinson SR (1995) Nutrient management of forages. In Barnes RF, Nelson CJ, Moore $\mathrm{KJ}$, Collins M (ed) Forages. Vol. 2. The science of grassland agriculture, 6th edn. Blackwell, Ames.

Freitas MSC (2012) Decomposição e liberação de nutrientes de estercos em função da profundidade e do tempo de incorporação. Revista semiárido de Visu. 2(1):150-161.

Haynes RJ and Williams PH (1993) Nutrient cycling and soil fertility in the grazed pasture ecosystem. Advances in Agronomy. 49:119-199.

Hirata M, Hasegawa N, Nomura M, Ito H, Nogami K, Sonoda $\mathrm{T}$ (2009) Deposition and decomposition of cattle dung in forest grazing in southern Kyushu, Japan. Ecol Res. 24: 119-125.

Hoffmann I, Gerling D, Kyiogwom UB, Mané-Bielfeldt A (2001) Farmers management strategies to maintain soil fertility in a remote area in northwest Nigeria. Agr Ecosyst Environ. 86:263-275.

Heal OW et al. (1997) Plant litter quality and decomposition: An historical overview. In Cadisch G and Giller KE (ed) Driven by nature: Plant litter quality and decomposition. CAB International, Wallingford, UK.

Instituto de tecnologia de Pernambuco, ITEP (2012) Visited on $15^{\text {th }}$ November, 2012. Available at: http://www.itep.br Johnson DW, Cheng W, Burke IC (2000) Biotic and abiotic nitrogen retention in a variety of forest soils. Soil Sci Soc Am J. 64:1503-1514. 
Mathews BW, Sollenberger LE, Nair VD, and Staples CR (1994) Impact of Grazing Management on Soil Nitrogen, Phosphorus, Potassium, and Sulfur Distribution. J Environ Qual. 23: 1006-1013.

Nicolardot B, Recous S, Mary B (2001) Simulation of C and N mineralization during crop residue decomposition: a simple dynamic model based on the $\mathrm{C} / \mathrm{N}$ ratio of the residues. Plant Soil. 228:83-103.

Pell AN and Schofield P (1993) Computerized monitoring of gas production to measure forage digestion in vitro. J Dairy Sci. 76(9):1063-1073.

Russelle MP (2008) Biological dinitrogen fixation in agriculture. Am Soc Agron, Crop Sci Soc Am, and Soil Sci Soc Am. 1:281-359.

SAS Institute (2001) Statistical analysis systems user's guide: version 8.2. 6th ed. Statistical analysis system institute. Cary, NC. USA, 199.

Santos ERS, Lira CC, Dubeux Jr. JCB, Santos MVF, Lira MA, Mello ACL, Cabral FA, Santos AMG (2011) Comportamento animal em pastagens consorciadas de gramíneas e leguminosas arbustivas na zona da mata de Pernambuco. In: XXI Congresso brasileiro de zootecnia, Maceió - AL, Brazil.

Silva WM, Cremon C, Mapeli NC, Ferri M, et al. (2010) Atividade microbiana e decomposição de diferentes resíduos orgânicos em um solo sob condições de campo e estresse hídrico simulado. Agrarian. 2(6):33-46.
Silva HMS, Dubeux Jr. JCB, Santos MVF, Lira MA, Lira Jr. MA, Muir JP (2012) Signal grass litter decomposition rate increases with inclusion of calopo. Crop Sci. 52:1416-1423.

Silva DJ and Queiroz AC (2002) Análises de alimentos (métodos químicos e biológicos). 3ed. UFV, Viçosa, MG, Brazil. 235.

Silva EE, Azevedo PHS, De-Polli H (2007) Determinação do carbono da biomassa microbiana do solo (BMS-C). Seropédica: Embrapa Agrobiologia. 6.

Souto PC, Souto JS, Santos RV, Araujo GT, Souto LS (2005) Decomposição de estercos dispostos em diferentes profundidades em área degradada no semi-árido da Paraíba. Rev Bras Cienc Solo. 29:125-130.

Suter M, Connolly J, Finn JA, Loges R, Kirwan L, Sebastia MT, Luscher A (2015) Nitrogen yield advantage from grasslegume mixtures is robust over a wide range of legume proportions and environmental conditions. Global Change Biol. 21, 2424-2438.

Van Soest PJ, Robertson JB, Lewis BA (1991) Methods for dietary fiber, neutral detergent fiber, and nonstarch polysaccharides in relation to animal nutrition. J Dairy Sci. 74(10):3583-3597.

Wagner GH and Wolf DC (1999) Carbon transformation and soil organic matter formations. In: Sylvia DM et al. (edn) Principles and applications of soil microbiology. Prentice Hall: Englewood Cliffs, NJ. 218-258.

Weeda WC (1967) The effect of cattle dung patches on pasture growth, botanical composition, and pasture utilization. New Zeal J Agr Res. 10(1):150-159. 